\title{
グループホームにおける居住者の滞在拠点形成についての基礎的考察
}

認知症高齢者グループホームでの生活に居室水準がもたらす影響に関する研究 第 1 報

\section{AN PRIMARY ANALYSIS OF FORMATION OF THE BASE IN DAILY LIVING OF RESIDENTS WITH DEMENTIA IN GROUP HOME}

Effectiveness on the living conditions of private room in the group home for dementia Part 1

\author{
黄 昞 峻*, 鈴木義弘** \\ Byungjoon HWANG and Yoshihiro SUZUKI
}

\begin{abstract}
This study tried to analyze the effectiveness on the quality of private room in group home for the elderly with dementia, by the classification for 4types on the base of residents from the view of spending time and frequency to go back to their private rooms. As the result, formation of the base in their living caused not only by the characteristics belonging to residents themselves (physical conditions, terms of residency, kind of disease etc.), but also by the quality of private room in other words the spatial condition too.
\end{abstract}

Keywords : elderly with dementia, group home, private room, quality of private room, composition of private and common space, the base in daily living 認知症高齢者, グループホーム, 居室, 居室水準, 面積構成, 滞在拠点

1.はじめに

\section{1 研究の背景}

認知症高齢者グループホーム（以下、GH）は、1997年の制度化 以後 10 年以上が経過しており、GHの重要性については、もはや論を またぬところであるが、2006年4月に改正された介護保険制度におい て、看取り（ターミナルケア）の促進が謳われおり、GHは住まい とケアの側面での役割は益々多大となっている。

これまでGHの建築計画に関する研究は数多く行われている。外 $山^{1)}$ は、高齢者の生活空間論において、在宅で暮らしてきた高齢者 が、生活の場を施設に移したとき経験させられる空間・時間・規則・ 言葉・役割の喪失などの落差を強調しており、その落差を埋めるた めの生活空間のあり方について、身の置き所としての個室を保障す ることの重要性や、居室相互間および居室と共用空間の相互間の緩 衝空間である中間領域の重要性について論じている。

このような高齢者の生活空間論は、外山と共同研究を行いながら それぞれ独自性を加えて行った研究者に引き継がれ、石井ら 2),3), 4) は、入居者の生活行動に影響を与える環境構成要素を通じて GHの あり方を、厳ら ${ }^{5), 6), 7)}$ は、生活環境になじんでゆく過程での諸空間の 果たす役割を通じて、ケア環境のあり方を論じており、鈴木 ${ }^{8), 99,10), 11)}$ は、介護の視点から空間と入居者の生活やケアとの関係を考察して いる。

これらの研究の主眼は、GHや共同生活の有効性、居住者の生活 やケア環境としての多様な共用空間計画の重要性を示しているとい
うことができ、 GH居住の有効性を活かすためにも、共用空間の計 画は重要であり、その結果も否認できない。

その一方で、GHにおける共同性だけではなく、様々な個人の生活歴 を持つ高齢者にとって、自宅での生活や個性の維持は重要であり、これ らを継続するためにも個人生活の拠点としての居室の役割は大きいと考 えられる。このような入居者の個別性に着目している研究としては、 山田ら $\left.{ }^{12)},{ }^{13}\right)$ による固有の居場所という概念を用いて居住者の居場所 の選択やそこでの様態に着目し、居住者個々人の生活を捉え、固有 の居場所の形成を促す、個人的要素 (性格や好み、入居前の生活歴、 家族関係、日頃の思いや考え、認知症やADL等）に配慮することが 生活の場としてのGH建築や建築空間の構成に求められていると論 じており、さらに居室についていうと、わずかではあるが、守田ら 14) は居室面積の違いが居住者の生活展開に与える影響に関する研究、 森田ら ${ }^{15)}$ は和室・洋室・和洋折表室の異なる居室タイプによる居住 者やスタッフに与える影響に関する研究が挙げられる。

\section{2 研究の目的}

これらに加えて、本研究は、さらに認知症高齢者の住生活環境の 向上を図る要件の一つとして、GHの居室水準向上の必要性につい て考察することを目的とするものである。

筆者らは、これまで知的障害者のための GHに関するヨーロッパ の事例との比較研究を通じて、わが国のGHにおける居室水準の低 さを示し16), 17) 18), 19), 20)、これはもちろん高齢者居住にも適用される心゙ きこと、その水準は少なくとも一般住宅に示されている「誘導居住

* 大分大学大学院工学研究科 博士後期課程 $\cdot$ 工修

** 大分大学工学部福祉環境工学科 准教授・博士 (人間環境学) 
水準」であるべきことを指摘してきた注1)。この点に関して、近いと ころでは、石井 ${ }^{22} や$ 㛜ら $^{23)}$ も、「疑似家族的な集住体」から「個」 が重視されたGHのあり方の重要性に言及している。

このため、まず本稿では、認知症高齢者 $\mathrm{GH} の$ 居住者の生活行動 調查による滞在拠点形成の特徵について、認知症の程度や身体能力 などの居住者特性、および、居室の面積や設備水準などの空間特性 との関係性を考察する。これに続き次稿において、居住者の生活行 為を加えた分析を行い、考察を深めることとする。

また、居室を構成する要素は、面積、設備、部屋の形、音・空気・熱 環境、平面構成上の位置、外部の景色などを挙げられるが、ここでいう

「居室水準」とは、「居室面積水準」および「居室設備水準」を示して おり、この両者を総称する場合に「居室水準」と呼称する。

\section{3 研究調査の方法}

\section{1) 概要調査}

まず、大分県内に所在するGH全58ホームを対象にした悉皆調査 によって、61ユニット（42ホーム）の建物および居住者概要、平面 図の収集などを行った（表1）

表 1 調查対象 $\mathrm{GH}$ 一覧表

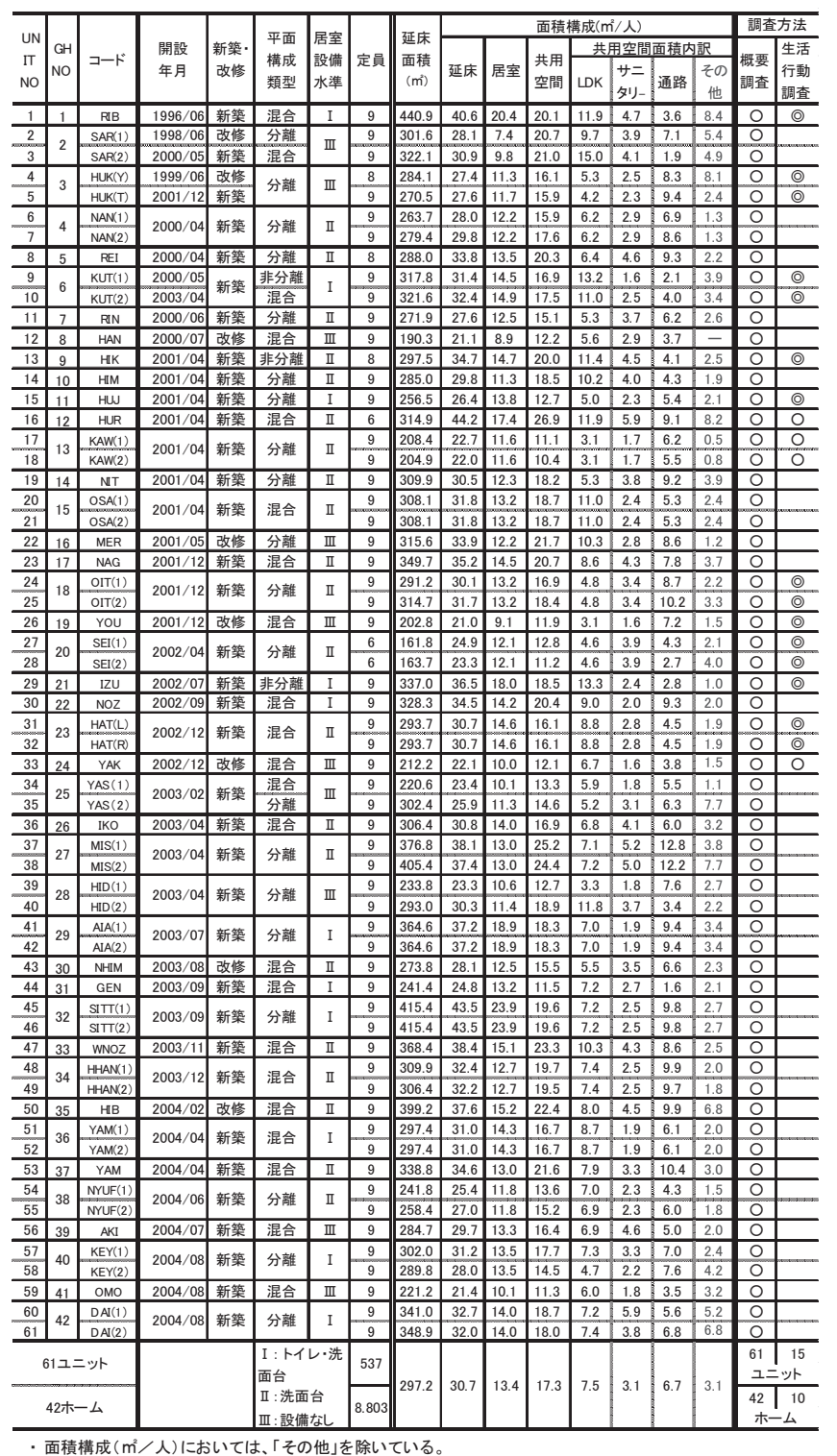

調查方法のうち生活行動調查の凡例: ○は予備調查のみ、は予備調查と本調查を行ったユニット

\section{2）生活行動調査}

予備調査は、33ユニット（24ホーム）のうち、19ユニット（13 ホーム）に実施した（表2）。本調査については、このなかから、 15ユニット（10ホーム）に対して実施したものである（表3）。

調査の方法として、調查員 2 人による非参与型の観察調查を 7 時か ら21時までの 14 時間、平日の 2 日間で行った。5分間隔に居住者の滞 在場所、行為、周囲の状況などを観察・記録した。また、5分毎の 定時の記録以外にも、居住者の動きや状況は絶えず観察・記録した (表2)

\begin{tabular}{|c|c|c|c|}
\hline \multirow{2}{*}{ 方法と内容 } & \multirow{2}{*}{ 概要調査 } & \multicolumn{2}{|c|}{ 生活行動調查 } \\
\hline & & 予備調查 & 本調查 \\
\hline 対象 & $\begin{array}{l}\text { 全58ホームのうち、 } \\
\text { 61ユニット(42ホーム) }\end{array}$ & $\begin{array}{l}\text { 19ユニット(13ホーム)、 } \\
\text { 158人 }\end{array}$ & $\begin{array}{l}\text { 15ユニット(10ホーム)、 } \\
\text { 123人 }\end{array}$ \\
\hline 調查期間 & 2002年9月 2004年8月 & $\begin{array}{l}\cdot 2003 \text { 年 } 10 \text { 月 11月 } \\
\cdot 07: 00 \sim 21: 00 の 14 \text { 時間 } \\
\text { (平日の1日間) }\end{array}$ & $\begin{array}{l}\cdot \text {-2004年8月〜11月 } \\
\cdot 07: 00 \sim 21: 00 の 14 \text { 時間 } \\
\text { (平日の2日間) }\end{array}$ \\
\hline 方法 & スタッフへの聞き取り調査 & \multicolumn{2}{|c|}{ 非参与式による居住者の行動観察調査 } \\
\hline 調査員 & $2 \sim 3 \curlywedge$ & \multicolumn{2}{|c|}{ 1ユニット当り2人 } \\
\hline 内容 & $\begin{array}{l}\cdot \text { ·建物、運営概要 } \\
\text { ·居住者概要 } \\
\text { ·平面図を入手及び採取 } \\
\text { •しつらえ採取 } \\
\text { ·写真撮影 }\end{array}$ & \multicolumn{2}{|c|}{$\begin{array}{l}\text { ·行動の時刻·場所·内容·様子について、5分間隔のマップ調査 } \\
\text { ‘連続的な観察·記録 } \\
\text { ·居住者の属性と生活歴、家族関係についてはススッフへの聞き } \\
\text { 取り調查 }\end{array}$} \\
\hline
\end{tabular}

表 3 生活行動調查対象ユニットと居住者の概要

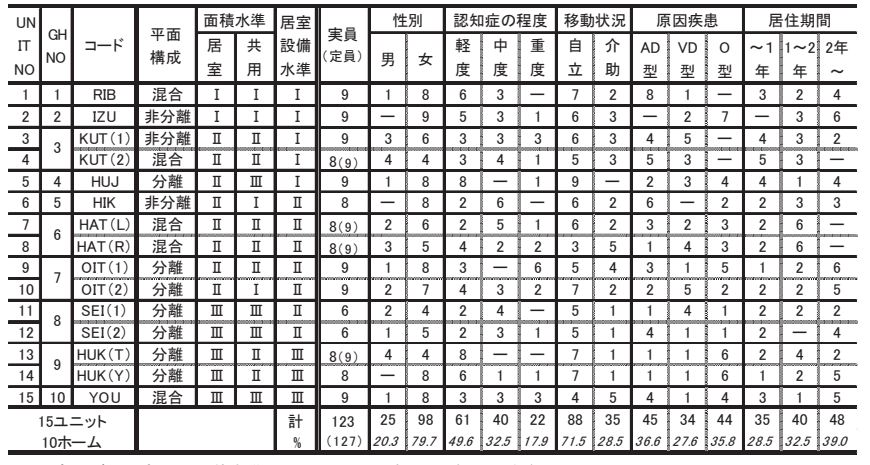

・居室及び共用空間の面皘水準 $(\mathrm{I} \cdot \boldsymbol{I I} \cdot$ 而の3 3分類) は、本文 3.4 を参照

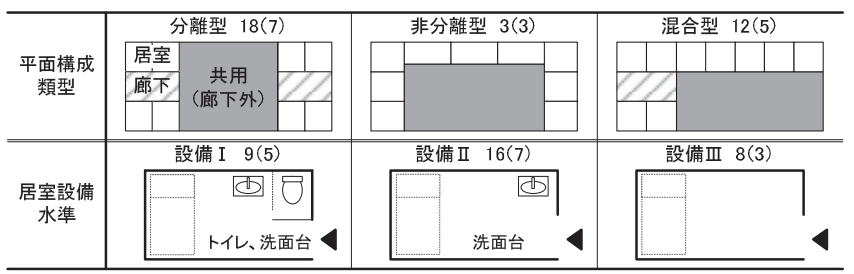

数值はユニット数であり、()は生活行動調査の選定対象数である。

図 1 平面構成と居室設備水準の類型

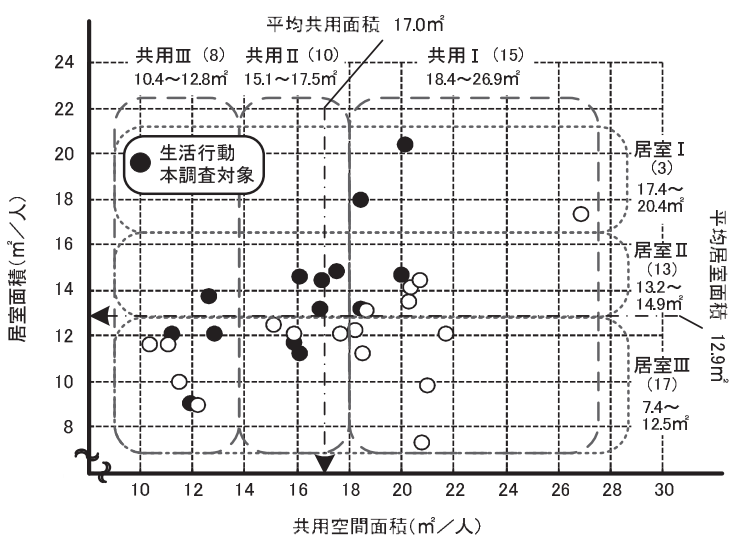

図 2 居室と共用空間の面積と構成比 
対象ユニットの選定にあたっては、予備調査対象の中から、下記 に示寸「空間特性」における各項目でのユニット相互の比較考察が 可能であり、かつまた、「居住者特性」において GH での生活行動 の特徴をとらえることのできるよう考慮した（表 3）。

<空間特性による指標 $>$

a. 平面構成の類型 : 居室と共用空間の配置形態で「分離型」「非分 離型」「混在型」に類型化し注2）（図1）、これらが分散すること。

b. 面積水準注3) : 定員 1 人あたりの居室と共用空間面積とその構成 比が分散すること（図 2)。

c. 居室の設備水準 : 居室における洗面台とトイレの有無で下記の 3 タイプに区分してとらえる。

＜居住者特性による指標 $>$

d. 認知症の程度注4) : 各ユニットにおける居住者の構成において、 認知症の程度が軽度者から重度者まで含まれていること。

e. 移動能力注5) : 移動が自力で可能な能力が「自立」か、何らかの 介助が必要な「要介助」か。

f. 原因疾患 : 認知症の原因は、アルツハイマー型（以下、 $\mathrm{AD}$ 型） と脳血管性（以下、VD型）に大別され、それぞれで行動特性も異な ることが指摘されている注6)。この原因疾患による生活行動の影響も 考慮する。そのため、調查では判然としなかったその他（以下、O 型）の居住者が多くなりすぎないこと。

\section{2. 面積構成からみた $\mathrm{GH}$ 特性}

本章では、概要調査を行った 61 ユニット（42ホーム）を対象とし て分析を行い、居室と共用空間の面積構成の傾向を捉える。

\section{1 居室および共用空間の面積構成}

定員1人あたりの延床面積は、21.1 $52.5 \mathrm{~m}^{2} / 人$ (平均は $33.8 \mathrm{~m}^{2} /$ 人）に分布し、ユニット間での格差が甚大である（図3）。

そのうち、居室（設備や収納を含めた居住者の専有面積）は、平 均 $13.4 \mathrm{~m}^{2} /$ 人で、突出した数例がみられるが、61ユニットのうち 49 ユニット $(80.3 \%)$ は、10 $15 \mathrm{~m}^{2} /$ 人の間に分布している。これに 対して、共用空間面積(注7) はGH間のバラッキが居室に比べて非常に

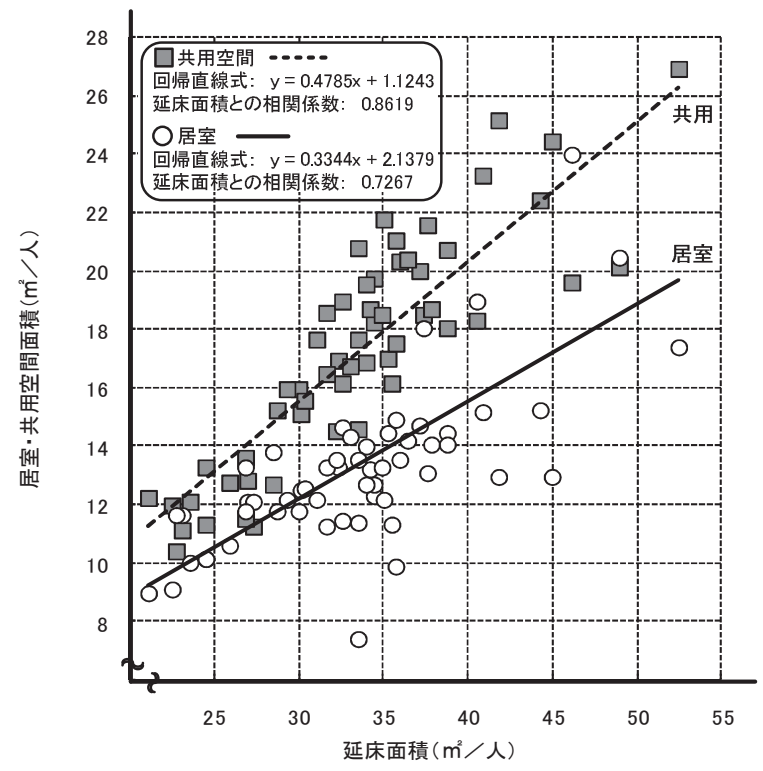

図 3 居室・共用空間面積と延床面積との相関
大きく、これを延床面積との関係をみるならば、共用空間面積との 相関が強い。すなわち、延床面積が広く確保されているGHにおい て、その分の面積的な余裕は、居室よりも共用空間に充当される傾 向にあるということが指摘できる注8)。

\section{2 居室の設備水準と占有面積}

一方、前章で規定した居室の設備水準では、洗面台・トイレとも に設置されているもの<設備 I > が17ユニット（27.9\%）、洗面台 のみ＜設備 II >が 30 ユニット $(49.2 \%)$ で、いずれも設置していな い事例＜設備 III $>$ も 14 ユニット $(23.0 \%)$ にみられる（図4）。

居室の占有面積注9) の平均は、<設備 I > < 設備III >でそれぞ れ、 $16.4 \mathrm{~m}^{2} /$ 人、 $13.0 \mathrm{~m}^{2} /$ 人、 $10.5 \mathrm{~m}^{2} /$ 人と、設備水準に対応した 違いがあるが、この面積から、衛生器具とこれを使用寸るための必 要寸法、および収納を除いた部分を算出注10) しても、それぞれ 12.6 $\mathrm{m}^{2} /$ 人、 $11.3 \mathrm{~m}^{2} /$ 人、 $9.8 \mathrm{~m}^{2} /$ 人となり、広さの序列は変わらず、面 積格差は小さくなるが、居室の有効面積に差違が認められる (図4)。

\section{3. 滞在拠点形成の特徵と要因}

15ユニット（10ホーム）に対する生活行動調査に基づき、居住者 のGHにおいて形成される滞在拠点の特徽を明らかにし、これに影 響をもたらす要因についての考察を行う。

\section{1 分析対象となる居住者の特徵}

分析対象の居住者は 123 人である。性別は、女性 98 人（79.7\%）、 男性が 25 人 (20.3\%) 、平均は各々 82.9 歳と 84.9 歳である (図5)。 認知症の程度と移動能力の関係では、移動自立の場合は、軽度 (55 /61人、90.2\%）>中度 $(26 / 40$ 人、 $65.0 \%)>$ 重度 $(7 / 22$ 人、31.8\%) の順になり、認知症が進行するほど、移動能力も低下している（図6）。

しかし、中・重度の認知症の移動状況については原因疾患による違い がみられ、 $\mathrm{AD}$ 型の 28 人中 20 人が移動自立であるが、一方、VD型は 19 人中 6 人のみである（図7）。

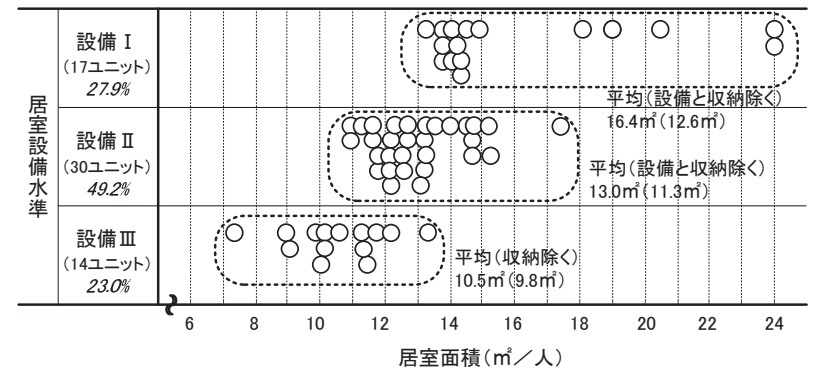

図 4 居室設備水準と占有面積

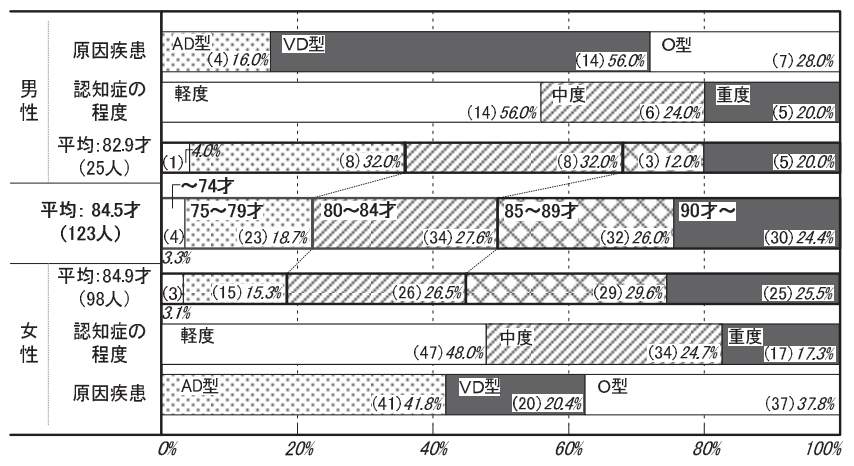

図 5 対象高齢者の年齢構成 
また、性別でみた認知症の程度別の分布は大きな差はみられない。し かし、認知症の原因疾患において、 $\mathrm{AD}$ 型の 45 人のうち男性は 4 人のみで、 VD型の 34 人のうち14人を男性が占め、本研究対象においては、男性 はVD型、女性はAD型の占める割合が高い点に留意する必要があ る（図5）。

居住期間は平均21.7ケ月で、1ヶ月から最大 64 ケまで幅広く、これら を 1 年未満、 1 年 $\sim 2$ 年未満、 2 年以上の 3 分類でみると、居住期間が長い居 住者ほじ認知症が進行している傾向であるが、居住期間 2 年以上で軽度を 維持している居住者も19人 (39.6\%) みられる(図8)。

\section{2 居住者の日中での帯在場所}

生活行動調查時間（7：00～21：00）における居住者の滞在場所 を、居室・共用空間・屋外に 3 分類して捉えると（図 9）、平均で は共用空間滞在が $65.1 \%$ あり、これは一日平均 9 時間あまりに相 当し、居室滞在は $30.8 \%$ （約 4 時間 20 分）である。この中には、 調查時間の $7: 00$ 以後も就寝していたり、21：00 前に床につく居 住者もいるため、これを除くと、共用空間滞在（71.7\%）は居室滞 在 $(23.9 \%)$ の 3 倍に広がる。以後の分析では、後者（就寝時間を 除いたデータ）を用いる。

\section{3 滞在拠点の類型化}

また、生活行動は当然ながら個人差も大きく（図10）、居室滞在 時間は0.8\%（6.5分／日）のものから 78.1\%（10時間30分／日）ま で広く分布しており、居室へ出入り寸る回数（以下、「居室移動頻 度」と呼称する) 注11) は1回／日にとどまるものから 20.5 回／日 (平 均では7.8回／日）におよぶものまでみられた。

これらの生活行動の違いがどのような条件によって生じるかを明 らかにするため、「居室滞在率」と「居室移動頻度」の2つの指標 を用いてクラスター分析注12)を行い、居住者を4タイプに類型化した (図 10）。これらを「滞在拠点」と総称することとする。

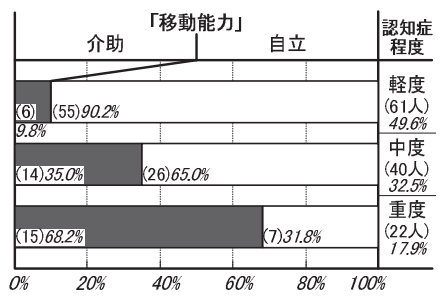

図 6 認知症の程度と移動状況

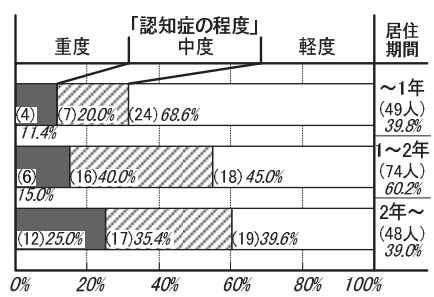

図 8 居住期間と認知症の程度

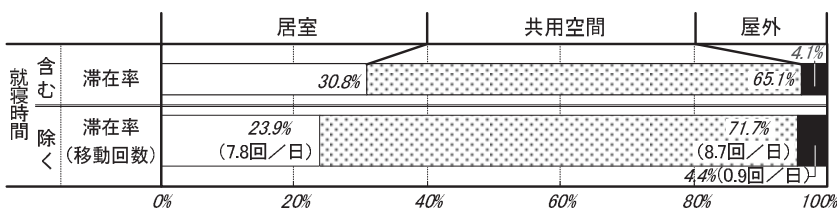

•ここでいう就蔓時間は、調査時間においても就寝をしている場合である。

図 9 空間滞在率と移動頻度
各類型は、居室での滞在が比較的長い居住者「居室拠点型 $<\mathrm{A}>」$ と、 共用空間滞在が長い居住者「共用滞在型 $<\mathrm{B}>」 に 2$ 分することができ、 さらに「居室移動頻度」の違いで下記の特徴をもつ（図11）。

<A1> : 21人 (17.1\%) 「居室滞在率」が高く、「居室移動頻度」も 多いタイプ。平均すると、居室と共用空間でほぼ同じ時間を過ごしており、 1回あたりの平均居室滞在は、約33分である。数値的には、活動性の高い生 活を行っていると評価できる。

<A2> : 12人 (9.8\%) 「居室滞在率」は高いが、「居室移動頻度」 は少ないタイプであり、居室での滞在率は平均 $57.7 \%$ 、1回あたりの平均居 室滞在は、約66分である。

$<$ B1 $>$ : 29人 (23.6\%) 「居室滞在率」は低いが、「居室移動頻度」 は多いタイプ。共用空間での滞在率は平均 $83.0 \%$ を占めるが、活動性は 高い生活である。

<B2> : 61人 (49.6\%) 「居室滞在率」が低く、「居室移動頻度」 も少ないため、基本的には日中の殆どを共用空間で過ごしているタイプ であり、このタイプが居住者の約半数を占めている。

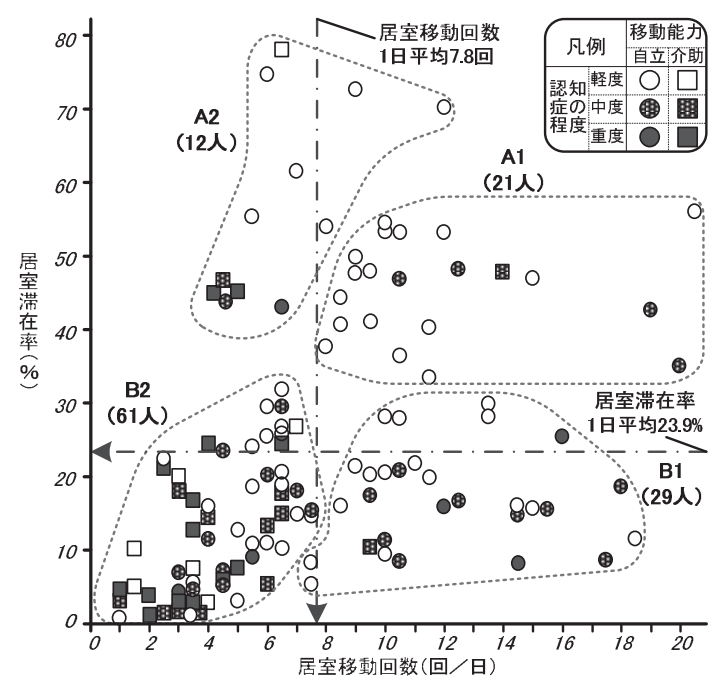

図 10 居室滞在率と移動回数による分類

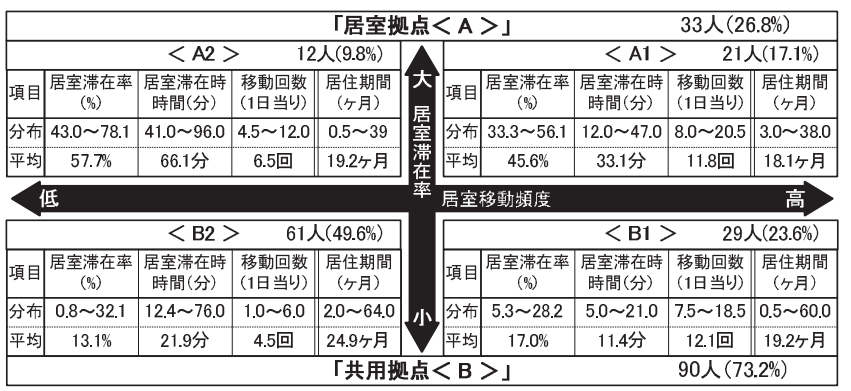

図 11 滞在拠点類型

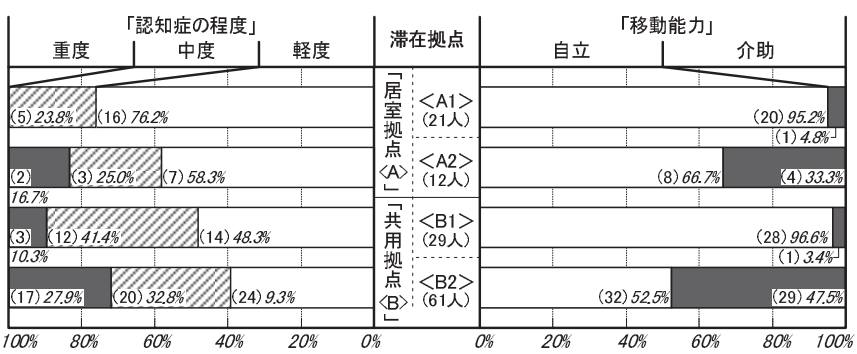

図 12 滞在拠点別の認知症の程度と移動能力 


\section{4 滞在拠点形成の要因分析}

\section{1）居住者特性に起因する滞在拠点形成の特徵}

(1) 認知症の程度および移動能力との関係

$<\mathrm{A} 1>$ タイプは、認知症の軽度者が $76.2 \%$ を占めており、 $<\mathrm{A} 2>\cdot<$ $\mathrm{B} 1>\cdot<\mathrm{B} 2>$ になるに従い、その比率は段階的に減少し、中・重度者の 比率が高くなる（図12）。

一方、「移動自立」の居住者は、この $<\mathrm{A} 1>(95.2 \%)$ とともに、 $<$ B1> (96.6\%) の出現率が突出しており、移動能力が「居室移動頻度」 に端的に反映している（図12）。

これらの相互関係をみてみると（図13）、軽度から重度になるに従い 「居室拠点型 $<\mathrm{A}>」$ が順次減少し、重度者での「共用拠点型 $<\mathrm{B}>」$ 」、 90.9\%にのぼるのに対し、「移動介助」は、認知症の程度にかかわらず 「移動自立」に比べて $<$ B $2>$ タイプの出現比率の極端に高いことが示差 的である。

これとは対極的な軽度でかつ「移動自立」の居住者（55人）について みれば、滞在拠点のタイプは比較的分散している。このことは、その他 の諸要因との関係を考察する上で有用であると考えられるため、これ以 降、適宜分析のための指標として用いることと寸る。

\section{(2) 認知症の原因疾患との関係}

認知症の原因疾患別の滞在拠点は、VD型の $38.2 \%$ （13／34人）が「居

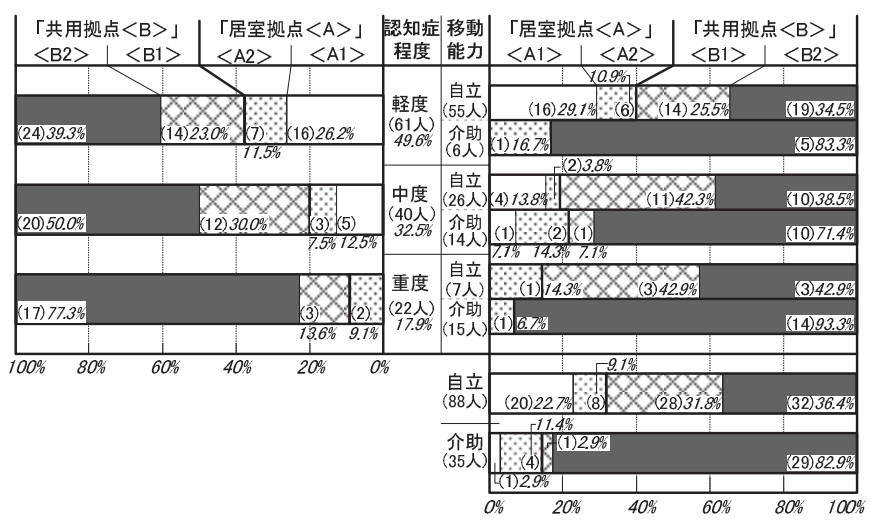

図 13 認知症の程度と移動能力別の滞在拠点

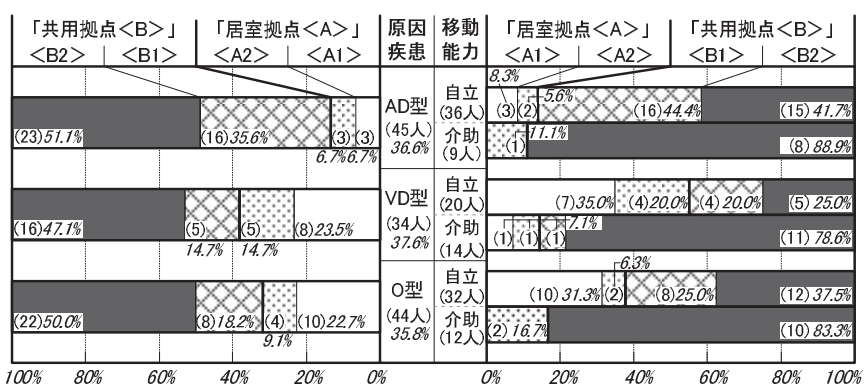

図 14 原因疾患と移動能力別の滞在拠点

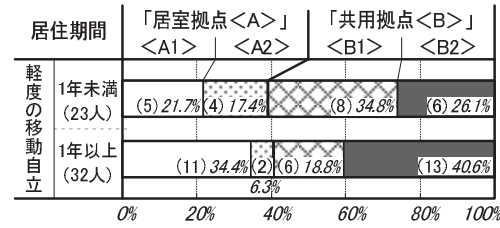

図 15 軽度の移動自立でみた居住 期間別の滞在拠点
室拠点型 $<\mathrm{A}>」$ なのに対して、 $\mathrm{AD}$ 型では $13.3 \%$ （6／45人）である。さ らに、「移動自立」に限ると、VD型は $55.0 \%$ 、 $\mathrm{AD}$ 型では $13.9 \%$ にとどま り、認知症の原因疾患による傾向の違いは増幅する（図14）。

$\mathrm{AD}$ 型は徘徊、移動、落ち着きのなさなどの行動特性が指摘されており 25),26)、これが反映しているとも考えることができる。

\section{(3) 居住期間と滞在拠点}

滞在拠点類型別の平均居住期間は（図11）、 $<\mathrm{A} 1>$ は18.1ヶ月、 $<\mathrm{A} 2$ $>$ と $<\mathrm{B} 1>$ は19.2ケ月であるが、これに対して $<$ B $2>$ ゲは24.9ケ月で、 若干の差異が認められるため、認知症が軽度の「移動自立」について、 居住期間1年未満とそれ以上で比較してみると（図15）、「居室拠点型く $\mathrm{A}>」$ と「共用拠点型 $<\mathrm{B}>」$ の構成比は変わらないが、それぞれにおけ る内訳に違いがみられ、 1 年以上の居住者では $<\mathrm{A} 1>$ と $<\mathrm{B} 2>$ が増加し ている。この現象面のみからいえば、居住期間が長期化するに伴い、居 室を拠点とした活動性の高い居住者＜A1＞と共用空間にとどまる傾向が 強くなるもの $<\mathrm{B} 2>$ に、生活行動が二極化している。

\section{(4) 性別 $\cdot$ 年齢と滞在拠点}

性别でみると、男性に「居室拠点型 $<A>」 か ゙ 44.0 \%$ みれるのに対して、 女性では $22.4 \%$ と半数であり、ことに、80歳未満の居住者において、刘極的 な違いが認められる（図16）。これは女性の 80 歳未満の居住者 18 人中 10 人が $\mathrm{AD}$ 型（男性は 80 歳未満 9 人中、 $\mathrm{AD}$ 型は 0 人、軽度者 5 人）にも起因す ることが考えられ、かつまた、男性の場合、介護者が不在になると比較 的軽度で若齢の段階で入居寸るのに対して、女性で若齢の場合には、 $\mathrm{AD}$

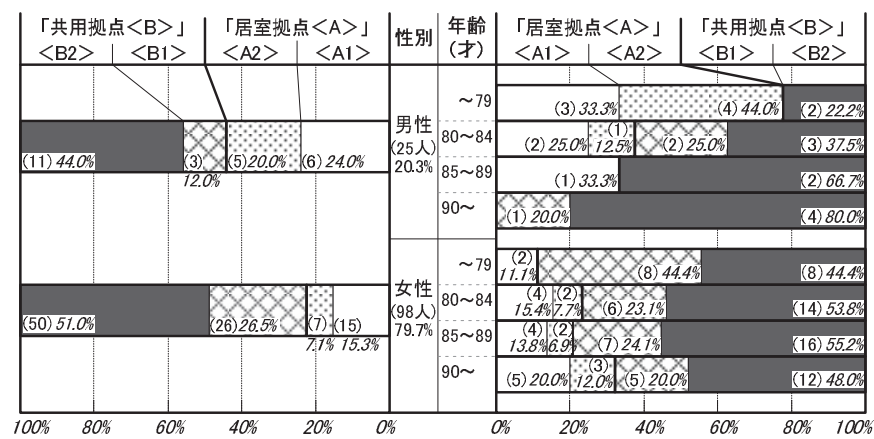

図 16 性別と年齢別の滞在拠点

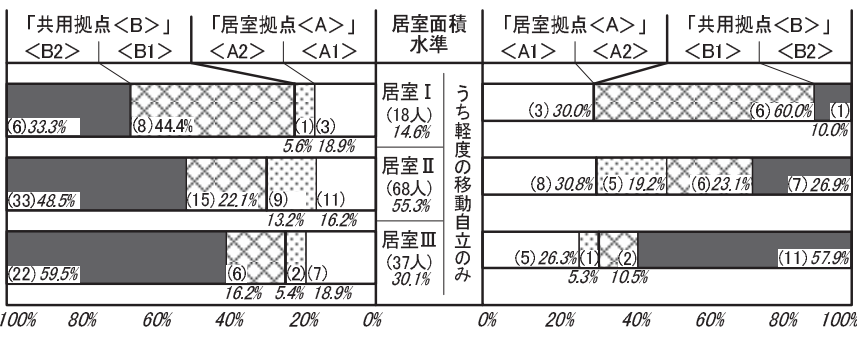

図 17 居室面積水準と滞在拠点

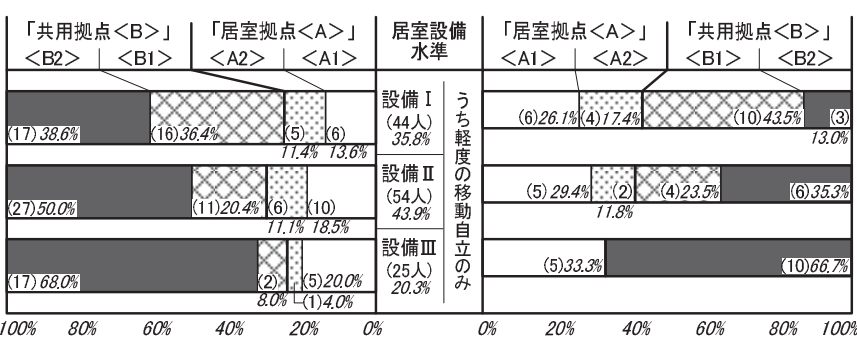

図 18 居室設備水準と滞在拠点 
型の発症に伴う介護の高まりが入居を促すという、複合要因が背景にあ るのではないかと推察できる29, 注13)。

\section{2）空間特性に起因する滞在拠点形成の特徵 \\ (1)居室水準との関係}

居室および共用空間の面積水準を3段階にグループ化し（図2）、 それぞれを居室 I （18.0～20.4 $\mathrm{m}^{2} /$ 人) ・居室 II （13.2～14.9 $\mathrm{m}^{2} /$ 人) ・居室III $\left(9.1 \sim 12.1 \mathrm{~m}^{2} /\right.$ 人)、共用 I $\left(18.4 \sim 20.1 \mathrm{~m}^{2} /\right.$ 人) ・共 用 II $\left(15.9 \sim 17.5 \mathrm{~m}^{2} /\right.$ 人 $)$ ・共用 III $\left(11.2 \sim 12.8 \mathrm{~m}^{2} /\right.$ 人) と呼称する。 さらに、「居室設備水準」も3 段階でとらえ（図1）、これら3つの指 標で滞在拠点類型をみた注14) (図17、18、19）。

「居室面積水準」と「居室設備水準」について滞在拠点との相関 をみるならば、いずれも、「居室拠点型 $<\mathrm{A}>」$ と「共用拠点型 $<\mathrm{B}>」$ の構成比については大きくは違わず、 $<\mathrm{A} 1>$ では $20 \%$ かそれをやや下回 る比率であるのだが、居室 I から居室III へ、また、設備 I から設備III と水淮が低下寸るに従って $<\mathrm{B} 1>$ が減少し、その分だけ $<\mathrm{B} 2>$ が増加す るという明確なトレードオフの相関がある主15) (図17、18)。

さらに、これを認知症軽度者かつ「移動自立」の居住者のみでみると、 この傾向がより増幅される（図 17、18）。これに対し、「共用面積水準」 は、滞在拠点類型との関係性を見いだすことはできない（図 19）。

すなわち、「居室水準」の高さは、単に居室への移動を促すだけでな く、これが居室での拠点形成にも結び付く契機となる可能性も含んでい ることが指摘できる。

\section{(2)平面構成との関係}

さらに、居室が共用空間に面している（「隣接」している）か、接 していない（「分離」している）かについても、滞在拠点類型との関 係をみたが（図20）、明確な傾向を読みとることはできない。単純 には共用空間と居室の位置関係では、生活行動の特徵を捉えること はできず、この点については、次段階の詳細分析で考察を深めたい。

\section{4. 総括}

本稿では、居室と共用空間での滞在時間および居室への移動頻度 に基づいてGH居住者の日中生活の滞在拠点を4タイプに類型し、そ の滞在拠点形成に居住者特性および居室水準が与える影響について の基礎的な考察を行い、以下の点を明らかにした。

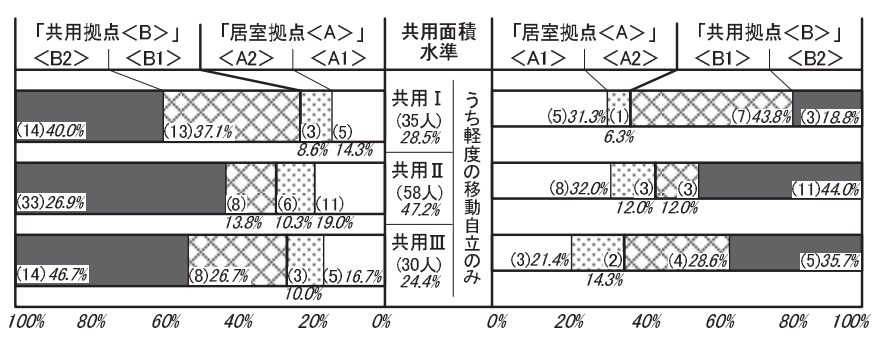

図 19 共用面積水準と滞在拠点

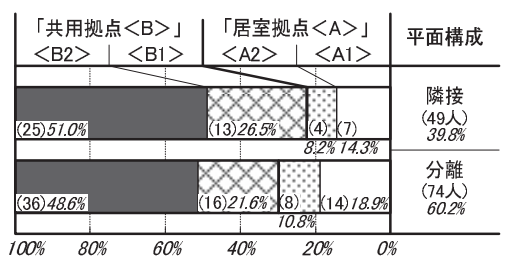

図 20 平面構成と滞在拠点

\section{1）居住者特性と滞在拠点の関係}

1. 認知症の軽度な場合あるいは移動能力の高い場合には、居室の滞在 率は高く移動頻度も多いが、裏を返せば、これらの悪化が共用空間滞在 の生活に転化する。

2. $\mathrm{AD}$ 型居住者は、移動能力が高くても共用空間での滞在率が高く、認知症 の原因疾患も滞在拠点形成の一要因となることが考えられる。

3. 居住期間の長期化は、GHでの生活に「なじむ」ことにもつながるが、 逆に移動の少ない 共用空間滞在の促進にもなりうる要素を含んでおり、これは、 軽度で移動能力の高い居住者にもあてはまる。

\section{2) 居室水準と滞在拠点の関係}

居室の面積および設備の水準、すなわち「居室水準」が高いほど、 移動頻度の少ない共用空間滞在は減少する。ことに軽度の認知症で 移動能力の高い居住者において、その傾向がさらに顕著であることが確 認された。

\section{3）居室と共用空間の面積構成}

しかしながら、本稿で示したもう一つの考察結果は、居室と共用空間 の面積配分に偏差がみられていることである。延床面積が広く確保され た場合、付加分は共用空間に充てられる傾向が指摘できる。その中で、 居室面積での格差も設備や収納の設置に起因しており、実質的な有効面 積は低水準に抑制されている。その反面で、「共用面積水準」は滞在拠 点形成に与える影響は認められなかった点も、今後さらに精査して評価 に加える必要があると考えている。

もちろん、滞在拠点が共用部分に遍在していることは必ずしも否 定的な側面のみではないであろう。居住者自身が共用空間拠点を望 んでいることもあろうし、また、重度化して移動能力が低い場合に は共用空間での滞在の有効性も高いと考えられるが、自律性を失っ た滞在もその中に含まれていることが懸念される。

本分析に引き続き、居住者の生活行為、寸なわち、居室での生活 行為や共用空間での私的行為についての分析を行い、居室水準向上 の有用性についての考察を深める予定である。

\section{謝辞}

調查においては、GHの居住者・家族の方々、およびスタッフの 皆様に多大なご協力を頂きました。この場を借りて深く御礼申し上 げます。

注

注1）非自立高齢者の居住水準に関する研究会の報告書（参考文献21）では、 第八期住宅建設五箇年計画（2001年）に定められている居住水準を見 直し、現在の寝室機能が主である居住空間に、生活機能を含んだ面積水 準へと居住水準向上の必要性について言及している。その後は、2006 年6月に制定された「住生活基本法」において、単身者の誘導居住面積 水淮、一般型が $55 \mathrm{~m}^{2}$ 、都市居住型が $40 \mathrm{~m}^{2}$ 、そして、最低居住面積水準 は $25 \mathrm{~m}^{2} に$ 明示されていて、これには高齢者や障害者が共同で居住する 場合も含むことが明記されている。

注2）参考文献24）の3つの分類を参照した。

注3）面積水準の分類において、居室面積は、 $11.0 \sim 15.0 \mathrm{~m}^{2} に 8$ 割近くが集中 して分布しており、 $15.0 \mathrm{~m}^{2}$ を超えるのは $17.4 \mathrm{~m}^{2} \sim 20.4 \mathrm{~m}^{2}$ のコニットを 一つの分類とし、集中分布するユニットは平均面積である $12.9 \mathrm{~m}^{2}$ を基準 として分類し、平均を超える13.2 14.9 $\mathrm{m}^{2}$ の 13 ユニットと、平均を下回 る7.4〜 $12.5 \mathrm{~m}^{2}$ の17ユニットに分類した。また、共用面積の分布にばら つきがみられ、10.4〜12.8 $\mathrm{m}^{2}$ にユニニト、15.1〜 $17.5 \mathrm{~m}^{2}$ は 10ユニット、 $18.4 \mathrm{~m}^{2}$ 以上では 15 ユニットが分布することから、3つに分類した。

注4）認知症の程度は厚生省の判定基準を用いた。認知症程度のランクは I , II a , II b （以上軽度） $\mathrm{III}, \mathrm{III} \mathrm{a}, \mathrm{IIIb}$ （以上中度） $\mathrm{IV}, \mathrm{M}$ （重度）である。 
注5）移動状況の分類としては、移動自立（i：自立で補助具不使用、ii : 自立 で補助具使用）、移動介助（iii : 介助で補助具不使用、iv : 介助で補助具 使用）に分類した。

注6）原因疾患において、 $\mathrm{AD}$ 型はアルツハイマー型認知症、VD型は脳血管性認 知症、 $\mathrm{O}$ 型は $\mathrm{AD} や \mathrm{VD}$ 型以外の原因疾患や不明を指している。（参考文献 25,26) では、 $\mathrm{AD}$ 型とVD型の心理特性と行動特性の違いを指摘しており、 分析では両者の精神症状の違いによる生活行為の相異をみるため、生活行 動観察調査の対象選定ではO型が少ないホームを選定している。

注7）共用空間のうち、スタッフ室、倉庫、ゲストルームや面会室などの「そ の他」領域の 1 人あたりの面積は、0.5 $8.4 \mathrm{~m}^{2} / 人\left(\right.$ 平均 $3.1 \mathrm{~m}^{2} /$ 人) で ある。スタッフ室は59ユニット、倉庫は43ユニットにみられるが、ゲ ストルームもしくは面会室は7ユニットしかみられない。すなわち、ユ ニット間の設置状況の違いと、居住者の日常生活行為領域ではないため 面積算定では除いている。従って、共用空間面積は、共用空間の「その 他」以外の部分である。

注8）面積構成の特徴については、既に（参考文献27）で公表している。さら に、知的障害者GHについても（参考文献28）で報告しており、参照され たい。

注9）各ユニットの平均で、収納も占有の場合は算入した数值である。

注10）居室のネット面積（有効面積）の算出については、トイレは $1.2 \sim 2.3$ $\mathrm{m}^{2}$ 、洗面台は $0.5 \sim 1.2 \mathrm{~m}^{2}$ 、収納は $0.8 \sim 2.0 \mathrm{~m}^{2}$ に分布している。また、設 備と収納が居室の入り口に集約して前室の形態になっている場合は、 内部の通路を含めて $3.2 \sim 11.1 \mathrm{~m}^{2}$ に分布しており、これらを占有面積か ら引いた值である。

注11）移動回数は、1日平均に換算して示している。

注12）クラスター分析は、ユークリッド距離によるグループ間平均連結法を 用いている。

注13）男女別の性別による行動特性の違いも考えられるが、本稿ではこれを 明らかにしておらず、この点に着目した研究を（参考文献29）に挙げ るにとどめた。

注14）居室トイレや洗面、収納を除いた居室の有効面積のみでみると、居室 I $\quad\left(12.4 \sim 17.2 \mathrm{~m}^{2}\right)$ 、居室 II $\left(10.5 \sim 12.8 \mathrm{~m}^{2}\right)$ 、居室 III $\left(9.1 \sim 10.5 \mathrm{~m}^{2}\right)$ であり、2.2で記述したように、広さの序列は大きく変わらず、面積格 差は小さくなるが、居室の有効面積に差違が認妨らる。

注15）設備のみの利用のために居室に移動している居住者は<B2>タイプの 設備 I 場合に相対的に多くあらわれてはいるが、全体の移動回数か らみると多くの比率を占めては抢らず、設備水準の高さが居室の滞在 拠点形成に寄与していることが考えられる (下表参照)。

\begin{tabular}{|c|c|c|c|c|c|c|}
\hline \multirow{3}{*}{$\begin{array}{l}\text { 滞在 } \\
\text { 拠点 }\end{array}$} & \multirow{3}{*}{$\begin{array}{l}\text { 居室 } \\
\text { 移動 }\end{array}$} & \multirow{3}{*}{$\begin{array}{l}\text { 平均居室 } \\
\text { 移動回数 }\end{array}$} & \multicolumn{4}{|c|}{ 平均居室設備利用のみの移動回数 } \\
\hline & & & \multirow{2}{*}{$\begin{array}{c}\text { 計 } \\
\text { (構成比) }\end{array}$} & \multicolumn{3}{|c|}{ 居室設備水準 } \\
\hline & & & & 設備 I & 設備 II & 設備亚 \\
\hline 居室 & A1 & 11.9 & $1.0(8.4 \%)$ & 2.2 & 0.9 & - \\
\hline 拠点 & $\mathrm{A} 2$ & 6.6 & $0.4(6.1 \%)$ & 0.6 & 0.3 & - \\
\hline 共用 & B1 & 12.1 & $2.5(21.3 \%)$ & 4.0 & 0.6 & - \\
\hline 拠点 & B2 & 4.5 & $0.9(19.4 \%)$ & 2.3 & 0.6 & 0.2 \\
\hline \multicolumn{2}{|c|}{ 計 } & 7.8 & $1.3(16.6 \%)$ & 2.6 & 0.6 & 0.1 \\
\hline
\end{tabular}

\section{参考文献}

1) 外山義 : 自宅ではない在宅 高齢者の生活空間論, 医学書院, 2003

2) 石井敏、外山義、長澤泰 : グループホームにおける生活構成と空間利用の 特性 痴呆性老人の環境構築に関する研究, 日本建築学会計画系論文集、 第502号，pp.103〜110，1997.12

3）石井敏、厳爽、外山義、橘弘志、長澤泰 : 先進事例にみる共用空間の構成 と生活の関わり 痴呆性高齢者のためのグループホームに関する研究 そ の1，日本建築学会計画系論文集，第524号，pp.109～115，1999.10

4) 石井敏、長澤泰 : 生活行動に影響を与える環境構成要素 痴呆性高齢者の ためのグループホームに関する研究 その 2 , 日本建築学会計画系論文集, 第553号, pp.123〜129，2002.3

5）厳爽、石井敏、外山義、橘弘志、長澤泰 : グループホームにおける空間利 用の時系列的変化に関寸る考察「なじみ」からみた痴呆性高齢者のケア環 境に関する研究 その1, 日本建築学会計画系論文集, 第523号, pp.155〜 $161,1999.9$

6）玈爽、石井敏、橘弘志、外山義、長澤泰 : グループホームにおける空間利 用の時系列的変化に関する考察「なじみ」からみた痴呆性高齢者のケア環 境に関する研究 その 2 、日本建築学会計画系論文集, 第5 28 号, pp.111〜 $117,2000.2$
7）厳爽、石井敏：継続的な視点から見た痴呆性高齢者グループホームの環境 とその変容に関する研究，日本建築学会計画系論文集，第569号, pp.55 $\sim 62,2003.7$

8）鈴木健二、外山義、三浦研 : 痴呆性高齢者グループホームにおける入居者 の生活の再編過程 痴呆性高齢者のケア環境のあり方に関する研究 (1)、 日本建築学会計画系論文集, 第546号, pp.121 126, 2001.8

9）鈴木健二、外山義、三浦研 : 痴呆性高齢者グループホームにおける入居者 の生活とスタッフの相互浸透 痴呆性高齢者のケア環境のあり方に関する 研究 (2), 日本建築学会計画系論文集, 第552号, pp.125〜131, 2002.2

10）鈴木健二、外山義、三浦研：痴呆性高齢者グループホームにおける空間 の構成と入居者の生活・スタッフのケアの展開 痴呆性高齢者のケア環境 のあり方に関する研究 (3), 日本建築学会計画系論文集, 第560号, pp.169 $\sim 176,2002.6$

11）鈴木健二、外山義、三浦研 : 痴呆性高齢者グループホームにおけるス夕 ッフの空間利用とケアの質的特性 痴呆性高齢者のケア環境のあり方に関 する研究 (4), 日本建築学会計画系論文集, 第563号, pp.163 170, 2003.1 12）山田あすか、上野淳、登張絵夢、竹宮健司：痴呆性高齢者グループホー ムにおける居住者による固有の居場所の選択とその要因, 日本建築学会計 画系論文集，第556号，pp.145～152，2002.6

13）山田あすか、上野淳 : 痴呆性高齢者グループホームの環境および居住者 の固有の居場所とその変容に関する研究, 日本建築学会計画系論文集, 第 592号, pp.93 100, 2005.6

14）守田幸代、中野明：痴呆性高齢者グループホームにおける生活領域から みた居室の計画に関する研究, 日本建築学会大会学術講演梗概集 $\mathrm{E}-1$, pp. $477 \sim 478,2003$

15）森田晃市、山口大輔、田中千歳、足立啓：痴呆性高齢者グループホーム における居室構成のあり方に関する研究 Kホームを事例として，日本建 築学会大会学術講演梗概集E-1，pp.293 294，2004

16）鈴木義弘ほか：知的障害者グループホームの居住水準向上のための基礎 的研究 第 $1 \sim 3$ 報, 日本建築学会大会学術講演梗概集E- $2, \quad$ p . 303 308, 2001

17）鈴木義弘ほか：知的障害者グループホーム入居者の住生活領域に関する 研究 第1 3 報, 日本建築学会大会学術講演梗概集E-2,pp.337〜342, 2002

18）鈴木義弘ほか：知的障害者グループホームの住居水準適正化にむけた事 例研究 第1 5報，日本建築学会九州支部研究報告，2003～2005

19）鈴木義弘：欧州諸国における知的障害者向けグループホームの居住水準 評価に関寸る調査研究，2002 04年度 科学研究費補助金基盤研究(B)(2) 海外学術研究 研究成果報告書, 2005.6

20）鈴木義弘、本間敏行：知的障害者向けグループホームの居住水準に関す る研究，住宅建築研究所報，No.30，pp.137～147，2003

21）「非自立高齢者の居住水準に関する研究」報告書，財団法人 高齢者住宅 財団, 2005.3

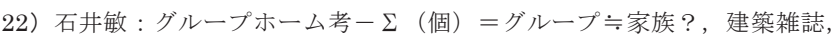
日本建築学会，第1561号，pp.12１3，2007.4

23）厳爽 : 平面分析による空間構成に関する考察 全国調查を通じてみた認知 症高齢者グループホームの現状に関する基礎的研究 その1, 日本建築学会 計画系論文集，第624号，pp.271～278，2008.2

24）林悦子、小滝一正、林玉子、大原一興、䒾輪裕子、前川佳史、佐藤哲 : 痴 呆性老人グループホームの建築計画に関する研究 (1)・(2)，日本建築 学会大会学術講演梗概集E-1, pp.255～258, 2000

25）雨宮克彦：痴呆老人の精神医学的分類とその行動特性 I, 病院建築, 日 本医療福祉建築協会，第111号，pp.26～28，1996.4

26）三宮基裕、片岡正喜、鈴木義弘：痴呆性高齢者の居住施設環境整備に関 寸る基礎的研究，日本建築学会計画系論文集，第 560 号，pp.111 118, 2002.10

27）廣瀬光伸、鈴木義弘、黄昞峻、乙益康二：痴呆性高齢者グループホーム の面積構成に関する研究, 日本建築学会大会学術講演梗概集 E-1, pp.287 $\sim 288,2004$

28）冨永加寿子、鈴木義弘：日本における知的障害者グループホームの現状 入居者概要と住居水準の基礎的分析，日本建築学会大会学術講演梗概集 E-2, pp.365 366, 2006

29）上和田茂、侯宇峰、江上徹：小規模地域分散型高齢者居住施設の共用空 間における行動特性の男女差に関する考察, 日本建築学会計画系論文集, 第 639 号，pp.1021 1028，2009.5

(2009年10月 9 日原稿受理， 2010年 3 月 4 日採用決定） 